\title{
NUTRITIONAL SUPPORT IN LONG TERM INTENSIVE CARE WITH SPECIAL REFERENCE TO VENTILATOR PATIENTS: A REVIEW
}

\author{
Hosni R. Bassili and Mervyn Deitel
}

\begin{abstract}
Patients requiring long term intensive care and/or prolonged ventilatory support, are frequently undergoing progressive malnutrition, occasionally complicated by a hypercatabolic state. Sepsis, fever and the requirements for postoperative healing will add further nutritional demands on such patients. In contrast to starvation, critically ill patients maintained on protein-free energy-deficient diet do not adapt to utilization of their lipid to provide energy needs. Mobilization of endogenous fat stores is reduced, and this reduction leads to increased gluconeogenesis from amino acids derived from muscle protein to meet the increased energy needs. Low serum albumin, possible low surfactant production, devitalization of the alveolocapillary membrane and impaired immunocompetence could contribute to the development of pulmonary transudation, alveolar collapse, low compliance and pulmonary infection. Such sequelae of a protein-free energy-deficient diet would delay weaning patients off prolonged mechanical ventilation. Nutritional assessment, which may be determined serially, and means of nutritional support are outlined.
\end{abstract}

KEY WORDS: INTENSIVE CARE, nutritional support; VentILATION, mechanical.

PATIENTS Requiring long term intensive care and/or prolonged ventilatory support, whether for medical, surgical or trauma indications, are frequently undergoing progressive malnutrition, occasionally complicated by a hypercatabolic state. Sepsis, fever and the requirements for postoperative healing will add further nutritional demands on such patients. The provision of adequate nutrition in the intensive care unit, although important, is frequently overlooked.

It is the purpose of this communication to examine the significance of adequate nutrition, whether by nasogastric tube or intravenous hyperalimentation, in long term intensive care and on the outcome of mechanical ventilation. The effects of a protein-free energy-deficient diet on the metabolism of critically ill patients will be discussed.

Protein and fat are the only two major energy resources. Proteins, unlike fat, have no reserves;

H.R. Bassili, M. B., B.Ch., F.R.C.P.(C), Department of Anaesthesia, St. Joseph's Health Centre, Toronto; M. Deitel, M.D., F.R.C.S.(C), F.A.C.S., F.I.C.S., F.A.C.G., Associate Professor of Surgery, University of Toronto, and Department of Surgery, St. Joseph's Health Centre, Toronto.

Supported by the St. Joseph's Hospital (Toronto) Research Foundation.

Address reprint requests to: Dr. H.R. Bassili, St. Joseph's Health Centre, 30 The Queensway, Toronto, Ontario M6R 1B5, Canada. 17

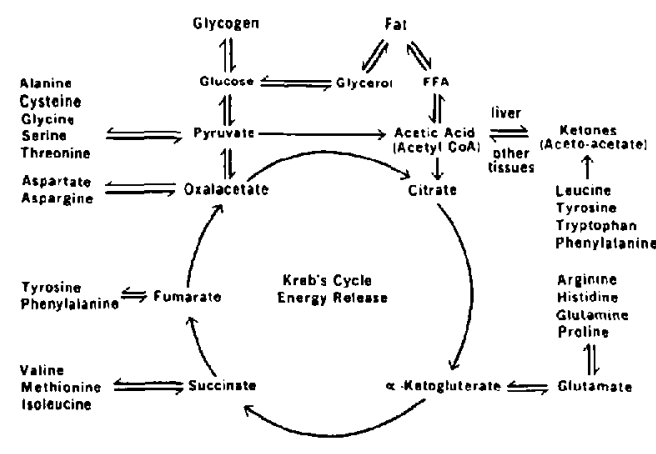

FIGURE 1 Interrelation of carbohydrate, protein and fat metabolism.

every protein serves a function (structure, antibody, enzyme, etc.). The interrelationship of carbohydrate, protein and fat metabolism is shown in Figure 1. In starvation or low-energy intake, adaptations occur to spare protein as an energy source. There are fundamental metabolic differences in man undergoing starvation and in patients exposed to stress, trauma or sepsis ${ }^{1}$ maintained on a protein-free energy-deficient diet.

\section{Metabolism in Starvation}

Three patterns of energy production are recognized: terminal glucose combustion to carbon dioxide and water mainly in the brain; glycolysis occurring in red blood cells; and utilization of free

Canad. Anaesth. Soc. J., vol. 28, no. 1, January 1981 
fatty acids (FFA) and ketones by the remainder of the body. 2

In early starvation urinary nitrogen rises, as protein is the chief source of blood glucose. After five to seven days of starvation the body adapts to using the fat depots as the major energy source, and urinary nitrogen decreases. Triglycerides are broken down to glycerol and FFA. In the liver glycerol is changed to glucose for brain consumption, and FFA are partially oxidized to produce ketones which are catabolized for energy by the peripheral tissues and later by the brain. ${ }^{3}$ Ketogenesis is thus a vital adaptation to prolonged starvation, sparing protein. The resynthesis of glucose from muscle pyruvate and lactate through the Cori cycle, utilizing lipid-derived energy, is a second adaptation to provide some glucose. Thus, since the complete oxidation of glucose to carbon dioxide and water is limited, glyconeogenesis from protein breakdown is diminished.

The low level of plasma insulin which occurs during starvation appears to be the primary regulator of FFA release. With low insulin, adenosine monopnosphate levels in adipose tissue rise and increase the activity of lipolytic enzymes which initiate triglyceride hydrolysis. ${ }^{4}$

\section{Effects of Trauma and Sepsis}

In contrast to starvation, critically ill patients (particularly the postoperative, post-traumatic, major burn or septic patients) are hypermetabolic, and the initial high rate of muscle protein catabolism continues. They do not adapt to utilization of lipid to provide energy needs. In addition to $6200-7500 \mathrm{~kJ} /$ day $(1500-1800 \mathrm{kcal})$ for basic maintenance, $1^{\circ} \mathrm{C}$ elevation of body temperature will increase daily energy requirements by about $4000 \mathrm{~kJ}$ ( $1000 \mathrm{kcal})$. Multiple fractures increase energy needs about 25 per cent and major burns 100 per cent. ${ }^{5}$

Insulin resistance occurs during both trauma and sepsis. ${ }^{6.7}$ There are high levels of both glucose and insulin in the blood. Mobilization of endogenous fat stores is reduced and this reduction leads to increased gluconeogenesis from amino acids derived from muscle protein to meet the increased energy needs. In the healing wound, the preferential utilization of glucose (and not ketones) for energy production to form the peptide-linkages needed for collagen synthesis adds further demand for gluconeogenesis. Gluconeogenesis is also stimulated by increased levels of glucocorticoids, catecholamines, glucagon and growth hormone. ${ }^{8}$ Although during star- vation muscle catabolism is inhibited by glucose intake, ${ }^{9}$ following major injury or sepsis the infusion of glucose does not inhibit gluconeogenesis. ${ }^{10,11}$

Thus, critically ill patients maintained on an energy-deficient protein-free diet undergo breakdown of muscle protein, in the face of increasing metabolic rate and reduced mobilization of fat stores.

\section{Effects of Protein-free Energy-deficient Diet on \\ Ventilator Patients}

During prolonged mechanical ventilation, the respiratory muscles subjected to only passive movement will undergo atrophy. Furthermore, like other skeletal muscles, the intercostal and diaphragmatic muscles will be cannibalized for energy needs. As protein depletion continues, visceral proteins such as albumin fall. Protein malnutrition is significant when serum albumin falls below $30 \mathrm{~g} / 1 .{ }^{12}$ As the colloid osmotic pressure falls, patients become susceptible to oedema, which is seen occasionally in ventilator patients. Visceral protein depletion is associated with impaired cell-mediated immunity, ${ }^{13.14}$ manifested by anergy (lack of reactivity) on delayed hypersensitivity skin-testing to common recall antigens. Anergy in postoperative or posttraumatic patients correlates with increased risk for sepsis and mortality. ${ }^{15}$ Nutritional repletion restores skin reactivity. ${ }^{16}$

The production of surfactant, a mucoprotein, may be reduced in patients who are in negative nitrogen balance. Furthermore, malnutrition may reduce replication of the respiratory epithelium and, in addition to inviting infection, this may be another factor contributing to laryngeal ulceration associated with prolonged intubation. In pure starvation, broncho-pneumonia is an ultimate cause of death. ${ }^{17}$

Low serum albumin, possible low surfactant production, devitalization of the alveolocapillary membrane and impaired immunocompetence could contribute to the development of pulmonary transudation, pulmonary collapse, low compliance and pulmonary infection. Such sequelae of a protein-free energy-deficient diet would delay weaning off prolonged mechanical ventilation. The use of intermittent mandatory ventilation as a stage in the weaning process to actively mobilize, replenish and synchronize the respiratory muscles after prolonged ventilation is justified.

Mattar, et al. ${ }^{18}$ reported in an abstract that 86 рег cent of 14 ventilator patients who had some 
means of nutritional support could be weaned off mechanical ventilation, compared to only 22 per cent of nine patients who received no nutrition. These results were similar to our findings in a retrospective study in our intensive care unit. We found that 90.9 per cent of 11 surgical patients (postoperative pulmonary complications, some associated with intra-abdominal sepsis) who had some means of nutritional support in the form of naso-gastric feeding or intravenous hyperalimentation could be weaned off mechanical ventilation, compared to only 36.3 per cent of 22 surgical patients with similar clinical problems who received only regular intravenous fluids.

\section{Nutritional Assessment}

It is helpful to establish the patient's nutritional status and progress. Visceral protein status can be determined by serum albumin (half-life 20 days) and serum transferrin (half-life eight days), ${ }^{19}$ the cell-mediated immune response as manifested by reactivity of greater than $5 \mathrm{~mm}$ to at least one skin-testing recall antigen (mumps, candida, PPD and streptokinase-streptodornase $)^{15}$ and by total lymphocyte count (W.B.C. $x$ per cent lymphocytes). ${ }^{20}$ Recently, serum proteins with very short half-lives (prealbumin 2 days, retinol-binding protein $12 \mathrm{hrs}$.) have been used as indicator of early malnutrition. ${ }^{21}$

Fat stores and skeletal muscle (somatic) protein status can be determined by anthropometric measurements. ${ }^{20}$ Triceps skinfold thickness (using a caliper) reflecting adipose reserves and arm circumference are measured at the midpoint between the acromion and olecranon. ${ }^{22}$ From these, the arm muscle circumference can be calculated in $\mathrm{cm}$ : midarm circumference minus 3.14 $\times$ triceps skinfold in $\mathrm{cm}$ (where $\pi=$ the constant 3.14). Measurements are compared to normal values. Creatinine/height index will also give a measure of the somatic protein status, since creatinine is liberated from skeletal muscle at a constant rate. ${ }^{20.23}$ The 24-hour urinary creatinine of the patient is divided by the expected 24-hour creatinine excretion of a normal adult of the same height.

\footnotetext{
Methods of Nutrition in Ventilator Patients

When the gastro-intestinal tract is functioning, enteral feeding is a simple, cheap and effective method of maintenance. Numerous excellent liquid diets ${ }^{24}$ which provide complete nutrition are available. To cite only a few, Ensure (Ross Laboratories) is low-residue, lactose-free, and
}

will not plug tubes; the hyperosmolar Vivonex products (Norwich-Eaton Pharmacals) are predigested or elemental, when secretory gut rest is necessary; the Precision ${ }^{\circledR}$ products (Doyle Pharmaceutical Company) are semi-elemental. When full concentration is achieved, they provide $4 \mathrm{~kJ}$ $(1 \mathrm{kcal}) / \mathrm{ml}$. Fine feeding tubes are well tolerated. ${ }^{25}$ If there is no diarrhoea, first the rate and then the concentration are increased.

Hyperosmolar dehydration secondary to glycosuria and diuresis may occur, particularly in diabetics. Blood and urinary glucose should be monitored before increasing the flow-rate. Urine should be free of sugar and blood glucose should be below $200 \mathrm{mg} / \mathrm{dl}$.

If the gastro-intestinal tract is not functioning, intravenous hyperalimentation should be used to provide about $200 \mathrm{~kJ}$ ( $40 \mathrm{kcal}) \cdot \mathrm{kg}^{-1} /$ day mainly from carbohydrate and $1.5 \mathrm{~g} \cdot \mathrm{kg}^{-1} /$ day of amino acid solution. ${ }^{26}$ This supplies an optimum metabolic ratio of $650 \mathrm{~kJ}(150 \mathrm{kcal}) / \mathrm{g}$ of nitrogen infused. ${ }^{27}$ Vitamins, electrolytes and trace elements are included. Essential fatty acid requirements are equivalent to about four per cent of daily energy intake, and may be provided by the infusion of $500 \mathrm{ml}$ of 10 per cent soybean or safflower oil emulsion (Nutralipid ${ }^{\circledR}$, Pharmacia Canada Ltd; Liposyn ${ }^{\circledR}$, Abbott Laboratories, North Chicago) two or three times per week. ${ }^{28}$ More lipid may be infused as a portion of the daily energy requirements and may have advantages in septic, injured, hypermetabolic patients. ${ }^{29}$

The daily volume of intravenous hyperalimentation is about $40 \mathrm{ml} / \mathrm{kg}$ in adults, adjusted with the fluid balance, cardiac status and temperature. Because of its hypertonicity, hyperalimentation is administered continuously through a central line. Catheterization of a central vein, preferably by the subclavicular route, which is relatively immobile and easy to maintain, should be carried out using strict aseptic technique. ${ }^{30}$ Intravenous hyperalimentation solution is individually prescribed, and prepared by the hospital pharmacy ${ }^{31}$ in a clean work station under a laminar-flow filtered-air hood. Intravenous hyperalimentation is expensive, but is safe with an organized team approach. ${ }^{32}$

\section{REFERENCES}

1. Border, J.R. Metabolic response to short-term starvation, sepsis, and trauma. Surg. Ann, 2: 11-34 (1970).

2. Cahill, G. F., JR, Starvation in man. N. Engl. J. Med. 282: 668-675 (1970).

3. OWen, O.E., Morgan, A.P., Kemp, H.G., Sul- 
livan, J.M., Herrera, M.G. \& Cahill, G.F., Jr. Brain metabolism during fasting. J. Clin. Invest. 46: 1589-1595 (1967).

4. Butcher, R.W. Role of cyclic AMP in hormone actions. N. Engl. J. Med. 279: 1378-1384 (1968).

5. Long, C.L., Schaffel, N., GeIGer, J.W. SCHILler, W.R. \& Blakemore, W.S. Metabolic response to injury and illness: Estimation of energy and protein needs from indirect calorimetry and nitrogen balance. JPEN 3: 452-456 (1979).

6. Sanderson, 1. \& Deitel, M. Insulin response in patients receiving concentrated infusions of glucose and casein hydrolysate for complete parenteral nutrition. Ann. Surg. 179: 387-394 (1974).

7. Gump, F.E., LONG, C., Killian, P. \& Kinney, J.M. Studies of glucose intolerance in septic injured patients. J. Trauma 14: 378-388 (1974).

8. Dahn, M., Boumman, D. \& Kirkpatrick, J. The sepsis-glucose intolerance riddle: A hormonal explanation. Surgery 86: 423-428 (1979)

9. O'Connell, R.C., Morgan, A.P., Aoki, T.T., BALL, M.R. \& Moore, F.D. Nitrogen conservation in starvation: graded responses to intravenous glucose. J. Clin. Endocrinol. Metab. 39: 555-563 (1974).

10. KinNeY, J.M., DUKe, J.H., JR., LONG, C.L. \& GuMP, G.E. Tissue fuel and weight loss after injury. J. Clin. Pathol. 23: 65-72 (1970).

11. Long, C.L., Kinney, J.M. \& Geiger, J.W. Nonsuppressability of gluconeogenesis by glucose in septic patients. Metabolism 25: 193-201 (1976).

12. Whitehead, R.G., Coward, W.A. \& LunN, P.G Serum-albumin concentration and the onset of kwashiorkor. Lancet I: 63-66 (1973).

13. LaW, D.K., Dudrick, S.J. \& ABdou, N.I Immunocompetence of patients with proteincalorie malnutrition. Ann. Intern. Med. 79 . 545-550 (1973).

14. Meakins, J.L., Pietsch, J.B., Bubenick, O., Kelly, R., Rode, H., Gordon, J. \& MacLean, L.D. Delayed hypersensitivity: indicator of acquired failure of host defenses in sepsis and trauma. Ann. Surg. 186: 241-250 (1977).

15. Maclean, L.D., Meakins, J.L., Taguchi, K., Duignan, J.P., Dhillon, K.S. \& Gordon, J. Host resistance in sepsis and trauma. Ann. Surg. 182: 207-217 (1975).

16. Copeland, E.M., MacFadyen, B.V., JR., \& DUDRICK, S.J. Effect of intravenous hyperalimentation on established delayed hypersensitivity in the cancer patient. Ann. Surg. 184: 60-64 (1976).

17. Moore, F.D. Metabolic Care of the Surgical Patient. Philadelphia, Saunders, pp. 412-422 (1959).

18. Matrar, J.A., Velasco, I.T., Esgaib, A.S. \& TAKAoka, F. Parenteral nutrition (PN) as a useful method for weaning patients from mechanical ventilation (MV). JPEN 2: Abst. 50 (1978).
19. Smith, M.F., Moldawer, L.L., Birstrian, B.R., Mascioli, E. \& Blackburn, G.L. Transferrin as a measure of efficiency of parenteral and enteral nutrition. JPEN $l$ : Abst. 9A (1977).

20. Blackburn, G.L., Bistrian, B.R., Maini, B.S. SCHLAMm, H.T. \& SMITh, M.F. Nutritional and metabolic assessment of the hospitalized patient. JPEN 1: 11-22 (1977).

21. Shetty, P.S., Jung, R.T., Watrasiewicz, K.E. \& JAMES, W.P.T. Rapid-turnover transportation proteins: an index of subclinical protein-surgery malnutrition. Lancet 2: 230-232 (1979).

22. FrISANCHO, A.R. Triceps skin fold and upper arm muscle size norms for assessment of nutritional status. Am. J. Clin. Nutr. 27: 1052-1058 (1974).

23. Bistrian, B.R., Blackburn, G.L., Sherman, M. \& SCRIMSHAw, N.S. Therapeutic index of nutritional depletion in hospitalized patients. Surg. Gynecol. Obstet. 141: 512-516 (1975).

24. KAY, R.M., BERNDL, L.A. \& HLAdYSheVsky, I. Elemental and liquid diets in surgery. In Nutrition in Clinical Surgery. Ed. Deitel, M. Baltimore, Williams \& Wilkins, pp. 29-4l (1980).

25. SANDLER, J.T. Specific techniques in delivery of liquid diets. In Nutrition in Clinical Surgery. Ed. Deitel, M. Baltimore, Williams \& Wilkins, pp. 43-52 (1980).

26. Deitel, M., Sauvé, F., SR., Alexander, M.A. DEGANI, C.T. \& ANAND, P.K. A crystalline amino acid solution for total parenteral nutrition. Can. J. Hosp. Pharm. 30: 175-179 (1977).

27. Long, C.L., Crosay, F., Geiger, J.W. \& KinNEY. J.M. Parenteral nutrition in the septic patient: nitrogen balance, limiting plasma amino acids, and calorie to nitrogen ratios. Am. J. Clin. Nutr. 29: 380-390 (1976).

28. Hew, L.R. \& Deitel, M. Nutrition in the cancer patient and the use of hyperalimentation. What's new in cancer care. West Coast Cancer Foundation. Volume III. Number 4 (1979).

29. Askanazi, J., Carpentier, Y.A., Elwyn, D.H., Nordenström, J., JeEvanandam, M., RosenBAUM, S.H., GUMP, F.E. \& KINNEY. J.M. Influence of total parenteral nutrition on fuel utilization in injury and sepsis. Ann. Surg. 191: 40-46 (1980).

30. Deitel, M., Sanderson, I. \& Petsoulas, T. A system of intravenous hyperalimentation. Internat. Surg. 58: 670-675 (1973)

31. Sauvé, F., Sr. Preparation of solutions for hyperalimentation. Can. J. Hosp. Pharm. 25: 60-62 (1972).

32. SANDERSON, 1. \& DEITEL, M. Intravenous hyperalimentation without sepsis. Surg. Gynecol. Obstet. 136: 577-585 (1973).

RÉSUMÉ

Les grands malades qui requièrent des soins intensifs à long terme, avec ou sans ventilation mécanique prolongée, évoluent souvent vers un état de dénutrition compliqué occasionnellement d'hypercatabolisme. L'infection, l'hyperthermie et la cicatrisation post-opératoire sont autant de facteurs qui viennent encore augmenter les besoins nutritionnels. Contrairement à ce qui survient dans le jeûne, il n'y a pas dans ces cas d'adaptation à l'utilisation des lipides comme source d'énergie lorsque les apports ne contiennent pas d'acides aminés et sont 
inférieurs aux besoins énergétiques. La mobilisation des réserves lipidiques endogènes est réduite et cette réduction conduit à une néoglucogénèse augmentée comme source d'énergie et ceci, aux dépens des amines aminés des protéines musculaires (y compris les muscles intercostaux et le diaphragme). Des albumines sériques abaissées, une production de surfactant diminuée, la dévitalisation de la membrane alvéolo-capillaire et un système immunologique d'efficacité réduite, peuvent contribuer à la survenue de transsudations pulmonaires, de collapsus alvéolaires, à de basses compliances et à l'infection pulmonaire. Une diète insuffisante en apport énergétique et sans apports aminés chez les grands malades peut donc être un facteur important dans les difficultés que l'on retrouve au sevrage de malades en ventilation prolongée. Il est essentiel de bien évaluer l'état nutritionnel dans ces situations. Les diverses méthodes de supports nutritionnels sont discutées. 